\title{
PENGARUH CORPORATE SOCIAL RESPONSIBILTY TERHADAP KINERJA KEUANGAN PERUSAHAAN
}

\author{
Nanik Lestari* \\ Novi Lelyta** \\ Politeknik Negeri Batam \\ *)nanik@polibatam.ac.id, **)novilelyta38@gmail.com
}

\begin{abstract}
This research aims to obtain empirical evidence on the influence of Corporate Social Responsibility impact on Corporate Financial Performance. Data used are non-financial companies in Indonesia Stock Exchange (IDX) period 2010-2015 as many as 419 samples. Corporate Financial Performance dependent variable is measured by Return on Asset (ROA) and Retunr on Invesment Capital (ROIC).The Independent variables of corporate Social Responsibility is adopted from the Global Reporting Initiative (GRI) G3.1 Guidelines with 6 indicators and 81 items. The control variables is Sales Growth. Data analysis technique used is panel data regression analysis. The results of this study are, the first Corporate Social Responsibility has positive on Corporate Financial Performance proxicated by ROA. The second, Corporate Social Responsibility has positive on Corporate Financial Performance proxicated by ROIC
\end{abstract}

Keywords: Corporate Social Responsibility, Financial Performance, ROIC, ROA

\section{PENDAHULUAN}

Menurut Nor (2011:48) pengertian Corporate Social Responsibility (CSR) adalah salah satu bentuk tindakan yang berangkat dari pertimbangan etis perusahaan yang diarahkan untuk meningkatkan ekonomi, yang disertai dengan peningkatan kualitas hidup bagi karyawan berikut keluarganya, serta sekaligus peningkatan kualitas hidup masyarakat sekitar dan masyarakat secara lebih luas. Dengan kata lain CSR adalah sebuah bentuk tanggung jawab perusahaan terhadap karyawan dan sumber daya yang dimanfaatkan dalam pelaksanaan bisnisnya. Selain melakukan bisnis dan mencari profit perusahaan harus bertanggung jawab atas kehidupan ekonomi daerah di mana perusahaan tersebut berada. Kepedulian terhadap lingkungan sangat dibutuhkan dalam CSR.

Pada tahun 2007 tepatnya Undang - Undang Nomor 40 tahun 2007 pasal 74 Undangundang Perseroan Terbatas (UUPT) yang baru menyebutkan bahwa PT yang menjalankan usaha di bidang dan atau bersangkutan dengan sumber daya alam wajib menjalankan tanggung jawab sosial dan lingkungan. UU No.25 Tahun 2007 tentang Penanaman Modal. Pasal 15 (b) menyatakan bahwa "Setiap penanam modal berkewajiban melaksanakan tanggung jawab sosial perusahaan". Selanjutnya lebih terperinci adalah UU No.19 Tahun 2003 tentang BUMN. UU ini kemudian dijabarkan lebih jauh oleh Peraturan Menteri Negara BUMN No.4 Tahun 2007 yang mengatur mulai dari besaran dana hingga tata cara pelaksanaan CSR. Undang-undang ini disahkan dalam sidang paripurna DPR.

Menurut Wibisono (2007:99), manfaat yang akan diterima dari pelaksanaan CSR bagi perusahaan. Terdapat empat manfaat yang diperoleh perusahaan dengan mengimplementasikan CSR. Pertama, keberadaan perusahaan dapat tumbuh dan berkelanjutan dan perusahaan mendapatkan citra yang positif dari masyarakat luas. Kedua, perusahaan lebih mudah memperoleh akses terhadap modal (capital). Ketiga, perusahaan dapat mempertahankan sumber daya manusia (human resources) yang berkualitas. Keempat, perusahaan dapat meningkatkan pengambilan keputusan pada hal-hal

EQUITY: Jurnal Ekonomi, Manajemen, Akuntansi | Vol. 22, No. 1 | 1 
yang kritis (critical decision making) dan mempermudah pengelolaan manajemen risiko (risk management).

CSR sesungguhnya sangat penting bagi perusahaan, dengan melakukan kegiatan CSR perusahaan pasti menerima keuntungan yang sangat banyak. Dikenali oleh masyarakat, masyarakat sangat antusias tentunya melihat perusahaan yang sangat peduli terhadap lingkungannya. Hal ini sudah dibuktikan oleh beberapa peneliti (Tsoutsoura, 2004) mencoba meneliti tentang hubungan Coporate Social Responsibility (CSR) dengan kinerja keuangan di Amerika Serikat. (Tsoutsoura, 2004) menyatakan bahwa terdapat hubungan positif dan signifikan antara CSR dan kinerja keuangan.

Menurut Kusumadilaga (2010), CSR berpengaruh signifikan terhadap nilai perusahaan sedangkan variabel profitabilitas sebagai variabel moderating tidak dapat mempengaruhi hubungan CSR dan nilai perusahaan. Dalam riset nya (Kusumadilaga, 2010) membedakan sebelum dan sesudah berlakunya UU Nomor 40 Tahun 2007 tentang Perseroan Terbatas.

Adapun riset ini terkait dengan pengaruh Corporate Social Responsibility (CSR) Terhadap Kinerja Keuangan Perusahaan yang Terdaftar Di Bursa Efek Indonesia. Riset ini merupakan replikasi dari penelitian (Oh \& Park, 2015) yang meneliti pengaruh CSR terhadap kinerja keuangan perusahaan di Korea. Pada penelitian Oh \& Park, (2015) menggunakan sampel perusahaan yang terdaftar di indeks KEJI di negara Korea. Adapun hasil dari penelitian menunjukkan bahwa CSR berpengaruh positif terhadap kinerja keuangan perusahaan. Maka dari itu peneliti ingin melakukan riset kembali apakah hasilnya tetap sama apabila di lakukan di Indonesia.

Pada penelitian Oh \& Park, (2015) menggunakan sampel perusahaan non keuangan maka dari itu, peneliti tetap menggunakan perusahaan non keuangan. Adapun alasan peneliti memilih non keuangan karena perusahaan non keuangan memiliki peraturan/regulasi khusus. Selain itu, dalam riset ini penulis mengukur variabel CSR dengan standar GRI G3.1 Guidelines. Alasan peneliti memilih standar ini karena sebagai pengganti dari indeks Keji yang ada di negara Korea.

\section{TINJAUAN PUSTAKA DAN PENGEMBANGAN HIPOTESIS \\ 2.1 Teori Legitimasi, Teori Stakeholder dan Kinerja Perusahaan}

Dowling dan Pfeffer (1975) menjelaskan bahwa dalam teori legitimasi organisasi berusaha menciptakan keselarasan antara nilai-nilai sosial yang ada pada kegiatan organisasi dengan norma-norma yang ada pada lingkungan sosial dimana organisasi merupakan bagian dalam lingkungan sosial. Dasar teori legitimasi adalah "kontrak sosial" yang terjadi antara perusahaan dengan masyarakat dimana perusahaan beroperasi. Ketika terdapat ketidakselarasan antara kedua sistem tersebut, maka akan muncul ancaman terhadap legitimasi perusahaan.

Donaldson dan Preston (1995) dalam stakeholder theory mengatakan bahwa kinerja sebuah organisasi dipengaruhi oleh semua stakeholder organisasi, oleh karena itu merupakan tanggung jawab manajerial untuk memberikan benefit kepada semua stakeholder yang berpengaruh terhadap kinerja organisasi. Stakeholder theory mengatakan bahwa perusahaan tidak beraktivitas hanya untuk kepentingan pemilik saham, melainkan juga bagi semua stakeholder lainnya (pemegang saham, kreditor, konsumen, supplier, pemerintah, masyarakat, analis, dan pihak lain).

Menurut Moerdiyanti (2010), kinerja perusahaan adalah hasil dari serangkaian proses bisnis yang mana dengan pengorbanan berbagai macam sumber daya yaitu bisa sumber daya manusia dan juga keuangan perusahaan. Apabila kinerja perusahaan meningkat, bisa dilihat dari gencarnya kegiatan perusahaan dalam rangka untuk menghasilkan keuntungan yang sebesar-besarnya. Keuntungan atau laba yang dihasilkan tentu akan berbeda tergantung dengan ukuran perusahaan yang bergerak.

EQUITY: Jurnal Ekonomi, Manajemen, Akuntansi | Vol. 22, No. 1 


\subsection{Kajian Literatur}

Bukti empiris dari penelitan sebelumnya terkait Corporate Social Responsibility terhadap Kinerja Keuangan Perusahaan menemukan hasil yang belum konsisten. Ada yang menemukan pengaruh positif dan ada yang menemukan pengaruh negative. Berikut penelitian yang menghasilkan CSR berpengaruh positif terhadap kinerja keuangan perusahaan.

Wijayanti, Sutaryo, \& Prabowo (2011), menguji pengaruh CSR terhadap kinerja keuangan perusahaan, dengan mengambil sampel 44 perusahaan manufaktur yang terdaftar di Bursa Efek Indonesia pada tahun 2008. Kinerja perusahaan diukur menggunakan return on aset (ROA), return on equity (ROE) dan earning per share (EPS). Hasil penelitian tersebut menemukan bahwa CSR hanya berpengaruh positif terhadap return on equity (ROE).

Rosiliana, Yuniarta, \& Darmawan (2014), bertujuan menguji pengaruh CSR terhadap kinerja perusahaan, dengan sampel 40 perusahaan yang terdaftar di Bursa Efek Indonesia periode 2008-2012. Kinerja perusahaan diproksikan dengan return on equity (ROE), return on asset (ROA), dan retur non sales (ROS). Hasil penelitian Rosiliana, Yuniarta, \& Darmawan (2014), menemukan bahwa CSR berpengaruh Positif terhadap ROA dan ROS, sedangkan CSR berpengaruh negatif terhadap ROE.

Candrayanthi \& Saputra (2013), menguji pengungkapan CSR terhadap kinerja perusahaan. Sampel yang diambil sebanyak 34 perusahaan pertambangan yang terdaftar di Bursa Efek Indonesia periode 2010-2011, kinerja perusahaan di proksi kan dengan return on aset (ROA), return on equity (ROE), dan net profit margin (NPM). Hasil penelitian tersebut menemukan bahwa CSR berpengaruh positif terhadap ROA dan ROE, sedangkan CSR berpengaruh negatif terhadap NPM.

Berikut penelitian yang menghasilkan CSR berpengaruh negatif terhadap kinerja keuangan perusahaan.

Yaparto, Frisko, \& Eriandani (2013), menguji pengaruh CSR terhadap kinerja keuangan, dengan 158 sampel perusahaan manufaktur yang terdaftar di Bursa Efek Indonesia periode 2010-2011. Kinerja perusahaan diproksikan dengan return on aset (ROA), return on equity (ROE), dan earning per share (EPS). Hasil penelitian tersebut menemukan bahwa CSR tidak berpengaruh signifikan terhadap kinerja keuangan.

Sindhudiptha \& Yasa (2013), menguji kinerja keuangan perusahaan memediasi hubungan antara CSR terhadap nilai perusahaan, dengan 303 sampel perusahaan yang terdaftar di Bursa Efek Indonesia periode 2009-2011. Kinerja perusahaan diproksikan dengan return on aset (ROA). Hasil penelitian (Sindhudiptha \& Yasa, 2013) menemukan bahwa kinerja keuangan perusahaan tidak mampu memediasi hubungan antara CSR terhadap nilai perusahaan. Maka dapat disimpulkan bahwa tidak ada hubungan kinerja perusahaan dengan CSR maupun nilai perusahaan.

\subsection{Pengembangan Hipotesis}

\section{Pengaruh Corporate Social Responsibility (CSR) terhadap Kinerja Keuangan Perusahaan}

Berdasarkan kajian literatur yang sudah dipaparkan, hipotesis dapat dibuat sesuai dengan penelitian sebelumnya. Oleh karena itu dapat disimpulkan bahwa CSR dapat berpengaruh positif dan dapat negatif atau tidak signifikan terhadap kinerja perusahaan. Penelitian yang berpengaruh positif terhadap kinerja perusahaan seperti penelitian oleh (Wijayanti, Sutaryo, \& Prabowo, 2011) dan (Candrayanthi \& Saputra, 2013) dengan pengaruh positif adanya pelaksanaan CSR, kinerja perusahaan akan meningkat dengan proksi return on aset (ROA) dan return on equity (ROE). 
Yaparto, Frisko, \& Eriandani (2013), menguji pengaruh CSR terhadap kinerja keuangan. Hasilnya tidak signifikan dalam konteks perusahaan manufaktur periode 20102011. Penelitian tersebut diperkuat oleh penelitian (Wijayanti, Sutaryo, \& Prabowo, 2011) yang menggunakan sampel manufaktur dengan tahun yang lebih terdahulu yaitu tahun 2008, dan penelitian (Candrayanthi \& Saputra, 2013) yang menggunakan sampel perusahaan pertambangan.

Berdasarkan penelitian di atas peneliti berargumen bahwa CSR dapat meningkatkan kinerja perusahaan. Oleh karena itu, peneliti dapat membuat hipotesis sebagai berikut:

$\mathbf{H}_{\mathbf{1}}$ : Corporate Social Responsibility berpengaruh positif terhadap kinerja perusahaan yang di proksikan dengan Retur on Assets (ROA)

$\mathbf{H}_{1 \mathbf{b}}$ : Corporate Social Responsibility berpengaruh positif terhadap kinerja perusahaan yang di proksikan dengan Return on Investment Capital (ROIC)

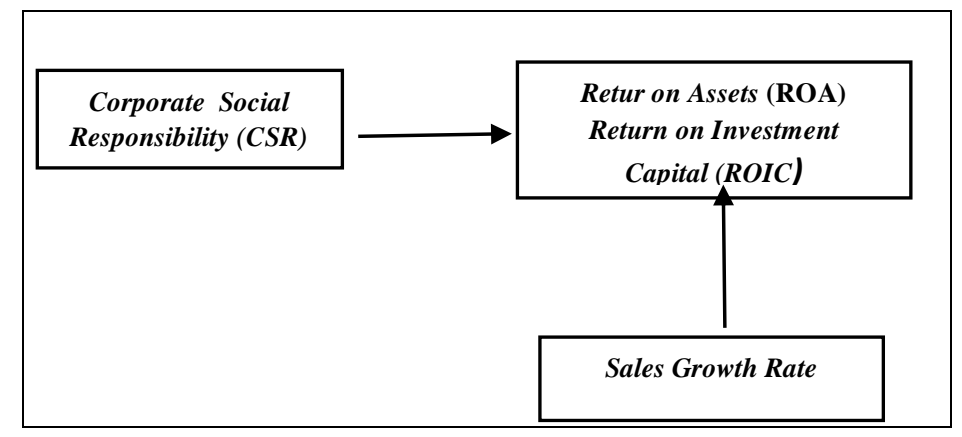

\section{Gambar 2.1 Model Penelitian Sumber: diolah sendiri}

\section{METODE PENELITIAN}

\subsection{Data dan Sampel}

Penelitian ini menggunakan sumber data sekunder yang berupa dokumen atau laporan keuangan dan laporan tahunan perusahaan yang terdaftar di Bursa Efek Indonesia (BEI) selama periode tahun 2010-2016. Data pada penelitian ini merupakan data panel yang merupakan gabungan dari data time series dan cross section. Skala pengukuran data yang digunakan dalam penelitian adalah skala rasio.

Populasi yang digunakan adalah perusahaan yang listing di Bursa Efek Indonesia. Teknik penarikan sampel menggunakan purposive sampling. Purposive sampling mempunyai arti bahwa sampel yang digunakan atau dipilih berdasarkan kriteria tertentu. Kriteria penarikan sampel sebagai berikut:

1. Perusahaan non-keuangan yang listing / terdaftar di Bursa Efek Indonesia dari tahun 2010-2016. Pemilihan semua perusahaan non keuangan karena memiliki regulasi pajak yang berbeda dibandingkan dengan sektor perusahaan pada umum nya.

2. Perusahaan yang periode pencatatan laporan keuangannya dimulai dari tanggal 1 Januari hingga 31 Desember. Bertujuan untuk menjaga keseragaman dalam penarikan sampel.

3. Perusahaan dalam menyajikan data laporan keuangan menggunakan mata uang rupiah (Rp). Penggunaan sampel dari data laporan keuangan tahunan perusahaan selain mata uang rupiah menimbulkan perbedaan akibat kurs yang selalu berubah meskipun dapat dikonversi.

4. Perusahaan yang memiliki data penyajian laporan tahunan dan keuangan yang lengkap terkait variable-variabel yang digunakan dalam penelitian. 
5. Perusahaan yang memiliki data lengkap (annual report) yang dibutuhkan untuk penelitian. Corporate Social Responsibility diungkapkan dalam laporan tahunan perusahaan dan jika data yang diperlukan tidak ada, tidak memungkinkan untuk melakukan pengukuran aktivitas Corporate Social Responsibility perusahaan tersebut.

6. Perusahaan yang memiliki data lengkap (annual report) yang dibutuhkan untuk penelitian. Corporate Social Responsibility diungkapkan secara tersendiri dalam laporan tahunan perusahaan dan jika data yang diperlukan tidak ada, tidak memungkinkan untuk melakukan pengukuran aktivitas Corporate Social Responsibility perusahaan tersebut.

Teknik pengumpulan data menggunakan basis data atau data sekunder yang berupa laporan tahunan dan laporan keuangan tahunan semua perusahaan non keuangan yang terdaftar di Bursa Efek Indonesia dari tahun 2010-2016. Data pendukung lain diperoleh dari buku, jurnal, makalah, website dan internet untuk melengkapi data penelitian. Pengolahan data dilakukan dengan proses tabulating dengan memasukkan data yang telah dikelompokkan dalam tabel-tabel agar dapat dimengerti dengan menggunakan program Microsoft Excel 2013, dan kemudian dilakukan analisis dengan menggunakan program aplikasi Eviews 9.

\subsection{Definisi Variabel}

Variabel dependen dalam penelitian ini adalah kinerja keuangan di mana diproksikan dengan Return on Asset (ROA) dan Return on Investment Capital (ROIC). Return on Asset (ROA) adalah satu rasio untuk mengukur profitabilitas perusahaan, yaitu dengan membagi laba bersih dengan rata-rata total aktiva. Di mana rata-rata total aktiva dapat diperoleh dari total aktiva awal tahun ditambah total aktiva akhir tahun dibagi dua. ROA juga dapat dicari dengan mengalikan Net Profit Margin dengan aset turnover. Aset turnover adalah penjualan bersih dibagi rata-rata total aktiva. Return on Investment Capital (ROIC) mencerminkan kemampuan manajemen merupakan tolak ukur kemampuan sebuah perusahaan menghasilkan laba dengan total modal sendiri yang digunakan. Rasio ini menunjukkan produktivitas dari seluruh dana perusahaan baik modal pinjaman maupun modal sendiri.

Variabel independen dalam penelitian ini yaitu Corporate Social Responsibility yang diadopsi dari Global Reporting Initiative (GRI) G3.1 Guidelines. Pengukuran pengungkapan Corporate Social Responsibility dilakukan dengan mencocokan indikator dengan cara metode check list pada item yang diungkapkan laporan tahunan perusahaan. Apabila item $\mathbf{y}$ diungkapkan maka diberi nilai 1 , jika item y tidak diungkapkan maka diberikan nilai 0 . Pengukuran aktivitas Corporate Social Responsibility diukur dari pengungkapan aktivitas Corporate Social Responsibility yang dilaporkan perusahaan dibagi dengan jumlah item pengungkapan.

Variabel kontrol dalam penelitian ini adalah CFP di nmana diproksikan dengan Sales Growth Rasio. Menurut Tambunan (2007), Sales Growth Ratio digunakan untuk mengukur pertumbuhan penjualan perusahaan dari tahun ke tahun. Perusahaan yang mengalami pertumbuhan penjualan dapat diketahui dari laba yang didapatkan dari aktivitas perusahaan dalam pengelolaan sumber daya di perusahaan.

\subsection{Model Penelitian}

Pendekatan yang digunakan dalam penelitian ini adalah pendekatan kuantitatif. Pendekatan kuantitatif diartikan sebagai metode penelitian yang digunakan untuk meneliti pada populasi atau sampel tertentu dengan tujuan untuk menguji hipotesis yang telah ditetapkan (Sugiyono, 2013). Model penelitian digunakan untuk menguji pengaruh aktivitas Corporate Social Responsibility (CSR) terhadap kinerja perusahaan. Adapun model penelitian sebagai berikut: 


\begin{tabular}{lll}
\cline { 2 - 2 } & \multicolumn{1}{c|}{ KPit $=\alpha+\beta 1$ CSRit $+\beta 2$ SGRit $+\varepsilon i t$} \\
Sumber: Diolah & \\
Keterangan: & \\
$\alpha$ & $:$ Kondiri \\
$\beta_{1}, \beta_{2}, \beta_{3}, \beta_{4}$ & $:$ Intersep \\
KPit & $:$ Kinerja Keuangan Perusahaan \\
CSRit & $:$ Corporate Social Responsibility perusahaan i pada tahun t \\
SGRit & $:$ Sales Growth
\end{tabular}

\section{HASIL DAN PEMBAHASAN}

Berdasarkan Tabel 1 dapat dilihat jumlah sampel dipilih berdasarkan kriteria-kriteria tertentu. Berdasarkan perusahaan non-keuangan yang terdaftar sebagai emiten non-keuangan untuk tahun 2010-2016 berjumlah 419 perusahaan. Selama periode penelitian terdapat 121 perusahaan yang tidak mengungkapkan laporan kegiatan CSR secara berturut-turut. Pelaporan keuangan yang menggunakan mata uang selain rupiah terdapat 132 perusahaan. Penulis tidak menemukan laporan keuangan berjumlah 71 perusahaan, sehingga total perusahaan yang menjadi sampel berjumlah 95 perusahaan dalam jangka waktu penelitian 7 tahun. Maka total observasi / sampel dalam penelitian ini sebanyak 665 (firm years).

Tabel 1 Hasil Penelitian Sampel

\begin{tabular}{lc}
\hline \multicolumn{1}{c}{ Kriteria } & $\begin{array}{c}\text { Jumlah } \\
\text { Perusahaan }\end{array}$ \\
\hline Perusahaan yang terdaftar selama 2010-2016 & 516 \\
\hline Perusahaan non-keuangan terdaftar selama 2010-2016 (data panel) & 419 \\
\hline $\begin{array}{l}\text { Perusahaan yang tidak mengungkapkan laporan CSR secara berturut- } \\
\text { turut }\end{array}$ & $(121)$ \\
\hline Pelaporan keuangan yang menggunakan mata uang selain rupiah & $(132)$ \\
\hline $\begin{array}{l}\text { Penulis tidak menemukan laporan keuangan } \\
\text { Total Sampel per tahun }\end{array}$ & $\frac{(71)}{95}$ \\
\hline Total observasi / sampel ( firm years ) & $\mathbf{6 6 5}$
\end{tabular}

Sumber: Factbook IDX 2010-2016

\subsection{Analisis Statistik Deskriptif}

Statistik deskriptif dilakukan dengan tujuan untuk mengenali pola sejumlah data, merangkum informasi dalam data tersebut dan menyajikannya dalam bentuk yang diinginkan. Adapun statistik deskriptif yang digunakan adalah Min, Max, Mean, dan standar deviasi.

Setelah melakukan statistik deskriptif penulis melakukan pengecekan data outlier. Data outlier adalah suatu data yang menyimpang dari sekumpulan data yang lain. Menurut Erlina \& Mulyani (2007) bahwa untuk menghilangkan data outlier dengan winsorizing yaitu mengubah nilai data outlier kesuatu nilai tertentu. Terdapat 14 sampel perusahaan yang memiliki data outlier, maka penulis melakukan winsorizing dengan cara mencari data yang berada diluar range dari \pm 3 kali standar deviasi dan mengganti data yang berada diluar batas atas dengan nilai batas atas tersebut, begitu pula dengan data yang berada dibawah batas bawah memakai nilai batas bawah. Statistik deskriptif dapat dilihat pada Tabel 2 sebagai berikut:

Tabel 2 Statistik Deskriptif 


\begin{tabular}{lccccc}
\hline & N & $\begin{array}{c}\text { Minimu } \\
\mathbf{m}\end{array}$ & Maximum & Mean & $\begin{array}{c}\text { Std. } \\
\text { Deviation }\end{array}$ \\
\hline CSR & 665 & 0.128 & 1.000 & 0.372 & 0.213 \\
\hline ROA & 665 & -9.040 & 9.938 & 2.261 & 3.752 \\
\hline ROIC & 665 & -0.099 & 0.140 & 0.023 & 0.038 \\
\hline SGR & 665 & -1.000 & 6.065 & 0.147 & 0.580
\end{tabular}

Keterangan: Tabel ini mempresentasikan hasil uji statistik. Seluruh hasil dari dari masing-masing variabel adalah dalam bentuk satuan. Variabel dependen $(\mathrm{ROA}=$ Return on Asset, $\mathrm{ROIC}=$ Return on Investmen Capital $)$ Variabel Independen (CSR=Corporate Social Responsibility). Variabel kontrol (SGR=Sales Growth)

Sumber: Data Sekunder diolah dengan Eviews 9, 2018

Berdasarkan statistik deskriptif tabel 2, pada Kinerja Keuangan Perusahaan dihitung perusahaan non keuangan di Indonesia periode 2010-2016 sebanyak 665 observasi. Variabel dependen berupa menggunakan Return on Asset (ROA) dan Return on Investment Capital (ROIC). Return on Asset (ROA) di hitung dengan laba bersih dibagi dengan total aktiva dikali 100. Nilai rata-rata ROA sebesar 2.261 atau 2261\%, hal ini berarti rata-rata kemampuan perusahaan menghasilkan laba sebesar $2261 \%$ dari total asset. Nilai tertinggi (maximum) ROA perusahaan pada tahun berjalan sebesar 9.938 dan nilai terendah (minimum) ROA perusahaan pada tahun berjalan sebesar -9.040, dan Return on Asset (ROA) memiliki nilai standar deviasi atau ketimpangan sebesar 3.752 dari keseluruhan rata-rata.

Return on Investment Capital (ROIC) dihitung dengan net profit after tax dibagi dengan total equity. Nilai rata-rata ROIC sebesar 0.023 atau $2.3 \%$. Hal ini berarti tingkat kemampuan perusahaan menghasilkan laba sebesar $2.3 \%$ dari modal / ekuitas. Nilai tertinggi (maximum) sebesar 0.140 dan nilai terendah (minimum) sebesar -0.099.Return on Investment Capital (ROIC) memiliki nilai standar deviasi atau ketimpangan sebesar 0.038 dari keseluruhan rata-rata.

Variabel independen yaitu pengungkapan Corporate Social Responsibility (CSR) yang diukur dengan 6 indikator pengungkapan CSR sebanyak 81 item. Nilai rata-rata CSR sebesar 0.372 yang artinya perusahan non keuangan tahun 2010-2016 rata-rata mengungkapkan $37.2 \%$ pengungkapan Corporate Social Responsibility. Nilai tertinggi (maximum) sebesar 1.000 dan nilai terendah (minimum) sebesar 0.128. CSR memiliki nilai standar deviasi atau ketimpangan sebesar 0.213 dari keseluruhan rata-rata.

Variabel kontrol dalam penelitian ini yaitu Sales Growth yang diukur dengan selisih antara penjualan tahun sekarang dengan penjualan tahun lalu dan dibagi dengan penjualan tahun lalu. Nilai rata-rata Sales Growth sebesar 0.147 yang menunjukkan bahwa pertumbuhan penjualan perusahaan selama tahun berjalan yaitu sebesar $14.7 \%$. Nilai tertinggi (maximum) sebesar 6.065 yang menunjukkan bahwa perusahaan yang mempunyai tingkat pertumbuhan penjualan tertinggi sebesar $606.5 \%$, sedangkan nilai terendah (minimum) sebesar -1.000, dan Sales Growth memiliki nilai standar deviasi atau ketimpangan sebesar 0.580 dari keseluruhan

\subsection{Pengaruh Corporate Social Responsibility terhadap Kinerja Keuangan Perusahaan.}

Hasil uji regresi data panel uji model diperoleh nilai probabilitas cross-section chisquare untuk variabel dependen ROA dan ROIC lebih kecil dari 0.05 yang menunjukkan konsistensi model Fixed Effect yang paling tepat digunakan untuk regresi data panel. Berdasarkan hasil ouput Eviews dapat dilihat pada tabel 3 sebagai berikut: 
Tabel 3 Analisis Regresi Pengaruh Corporate Social Responsibilty Terhadap Kinerja Keuangan Perusahaan.

\begin{tabular}{|c|c|c|c|c|c|c|}
\hline \multirow[b]{2}{*}{ Variabel } & \multicolumn{4}{|c|}{$\begin{array}{r}\text { KPit }=\alpha+\beta_{1} \mathbf{C S R}_{\text {it }}+\beta_{2} \mathbf{S G R}_{\text {it }}+\varepsilon i t \\
\text { Variabel Dependen }\end{array}$} & \multirow[b]{2}{*}{ ROIC } & \multirow[b]{2}{*}{ Prob. } \\
\hline & Coeficient & $\begin{array}{l}\text { ROA } \\
\text { t-Stat. }\end{array}$ & Prob. & Coeficient & & \\
\hline $\mathrm{C}$ & 0.425 & 1.491 & 0.137 & 0.003 & 1.296 & 0.195 \\
\hline CSR & 4.666 & 3.886 & $0.000 * * *$ & 0.049 & 7241. & 0.000 \\
\hline $\begin{array}{l}\text { SALES_GRO } \\
\text { WTH }\end{array}$ & 0.682 & 2.837 & $0.005 * * *$ & 0.007 & 2.864 & 0.004 \\
\hline R-Squared & & & 0.0 & & & 0.096 \\
\hline $\begin{array}{l}\text { Adjusted } \\
\text { R-Squared }\end{array}$ & & & 0.0 & & & 0.085 \\
\hline $\begin{array}{l}\text { F-statistic } \\
\text { Hasil Uji } \\
\text { Hausman }\end{array}$ & & & $\begin{array}{r}0.0 \\
\text { Fixed Effe }\end{array}$ & & & $\begin{array}{r}0.000 \\
\text { ed Effect }\end{array}$ \\
\hline
\end{tabular}

$\begin{array}{lrr}\mathbf{N} & 665 & 665\end{array}$

* Signifikan pada $\alpha 10 \% \quad$ ** Signifikan pada $\alpha 5 \% \quad$ *** Signifikan pada $\alpha 1 \%$

Keterangan: tabel ini mempresentasikan hasil pengujian hipotesis dengan metode fixed effect setelah dilakukan uji chow, dan hausman. Variabel dependen ROA sebagai proksi utama dan ROIC sebagai proksi pengukuran alternatif kinerja perusahaan untuk memperkuat hasil empiris penelitian. Variabel independen CSR, dan variabel kontrol terdiri atas Sales Growth. Penjelasan dari variabel tersebut adalah ROA $=\mathrm{LAba}$ Bersih $/$ Total Aktiva X 100. ROIC $=$ Net Profit After Tax / Total equity, CSR=Metode checklist tingkat pengungkapan Corporate Social Responsibility, Sales Growth= Penjualan (t) - Penjualan (t-1) / Penjualan (t-1)

Sumber: Data Sekunder diolah dengan Eviews 9, 2018

Pengujian ini bertujuan untuk mengetahui pengaruh dari variabel independen terhadap masing-masing variabel dependen. Keputusan menerima atau menolak model dengan melihat nilai probabilitas. Jika nilai probabilitas lebih kecil dari 0.05 maka variabel tersebut berpengaruh signifikan.

Berdasarkan hasil uji regresi pada Tabel 3 hipotesis menyatakan bahwa semakin baik implementasi Corporate Social Responsibility akan meningkatkan Kinerja Keuangan Perusahaan. Hipotesis tersebut menjelaskan hubungan positif Antara Corporate Social Responsibility terhadap Kinerja Keuangan Perusahaan. Dari hasil uji regresi hipotesis penelitian ini terdukung. Hasil tersebut sudah diuji dengan asumsi klasik. Nilai korelasi antar semua variabel yang digunakan dibawah 0,80 maka, dapat disimpulkan bahwa variabel yang digunakan bebas dari masalah multikolinieritas. Uji heteroskedastisitas menghasilkan nilai probabilitas untuk variabel dependen ROA 0.498 dan ROIC sebesar 0.575 lebih besar dari 0.05 , maka dapat disimpulkan bahwa variabel yang digunakan bebas dari masalah heterokedastisitas.

Variabel independen CSR diukur menggunakan variabel dependen ROA memiliki nilai t-statistik sebesar 0.659 dengan probabilitas 0.000 sehingga nilai probabilitas lebih kecil dari p-value 0.05. Sedangkan, Variabel independen CSR yang diukur menggunakan ROIC memiliki nilai t-statistik sebesar 7.242 dengan probabilitas 0.000 . Nilai $R$-Squared untuk variabel dependen ROA sebesar 0.094 lebih kecil dari 0.5, maka menunjukkan korelasi atau hubungan antara variable Corporate Social Responsibility dan Kinerja Keuangan Perusahaan adalah lemah, sedangkan untuk ROIC sebesar 0.096 yang menunjukkan korelasi atau hubungan antara variabel Kinerja Keuangan dan Corporate Social Responsibility juga samasama lemah. Demikian menjelaskan Kinerja Keuangan perusahaan diukur dengan variabel 
dependen ROA dapat dijelaskan oleh variabel CSR dan SGR hanya menjelaskan 9.4\%, sementara Kinerja Keuangan perusahaan diukur dengan variabel dependen ROIC mampu dijelaskan oleh variabel CSR dan SGR sebesar 9.6\%.Dalam penelitian ini juga terdapat variabel kontrol yang digunakan. SGR memiliki nilai probabilitas lebih kecil dari 0.05 artinya Sales Growth (SGR) berpengaruh terhadap Kinerja Keuangan Perusahaan.

Dari pembahasan yang telah dijabarkan diatas, hipotesis dalam penelitian ini menyatakan, H1a: terdukung. Semakin baik implementasi Corporate Social Responsibility perusahaan, akan meningkatkan Kinerja Keuangan Perusahaan, yang di proksikan dengan Return on Asset (ROA) terdukung. H1b: Semakin baik implementasi Corporate Social Responsibility perusahaan, akan meningkatkan Kinerja Keuangan Perusahaan yang di proksikan dengan Return on Investment (ROIC) terdukung.

Hasil pengujian yang diwakili oleh Return on Asset (ROA) maupun Return On Investment Capital (ROIC) menunjukkan bahwa CSR memiliki pengaruh positif terhadap Kinerja Keuangan Perusahaan, sehingga kegiatan CSR yang dilakukan mempengaruhi perusahaan untuk meningkatkan Kinerja Keuangan Perusahaan. Hal ini mengindikasikan beberapa indikator aktivitas CSR yang dilakukan perusahaan dapat meningkatkan kemampuan perusahaan menghasilkan laba.

Hasil penelitian ini sama dengan penelitian yang dilakukan oleh Pramesti (2012) yang menyatakan bahwa CSR berpengaruh positif terhadap Kinerja Keuangan Perusahaan. Dengan demikian Hasil penelitian ini dapat mengurangi anggapan bahwa perusahaan yang memiliki penerapan CSR yang berbiaya besar mengurangi return yang diharapkan investor. Penelitian ini juga sejalan dengan penelitian yang dilakukan oleh Rosiliana, Yuniarta, \& Darmawan (2014) yang menyatakan bahwa semakin banyak aktivitas CSR yang dipublikasikan perusahaan maka kinerja keuangan juga akan meningkat.

Hasil penelitian ini tidak sama dengan penelitian yang dilakukan oleh Yaparto, Frisko, \& Eriandani (2013) yang menyatakan bahwa CSR tidak memberikan pengaruh signifikan terhadap semua rasio keuangan yang digunakan. Penelitian ini juga tidak sejalan dengan penelitian yang dilakukan oleh Priyanka (2013) yang menyatakan bahwa semakin tinggi indeks pengungkapan CSR yang dilakukan perusahaan, tidak berpengaruh secara signifikan pada peningkatan pengembalian ekuitas atau Return on Equity (ROE) yang diperoleh perusahaan.

\section{SIMPULAN DAN KETERBATASAN}

\subsection{Simpulan}

Penelitian ini bertujuan untuk menguji pengaruh Corporate Social Responsibility terhadap Tax Avoidance. Penelitian ini menggunakan sampel perusahaan sektor non keuangan yang terdaftar di Bursa Efek Indonesia (BEI) selama periode 2010-2015 dengan jumlah 402 sampel perusahaan. Corporate Social Responsibility diadopsi dari Global Reporting Initiative (GRI) G3.1 Guidelines yang diukur menggunakan Effective Tax Rate dan Book Tax Differences. Hasil penelitian ini menemukan Corporate Social Responsibility tidak berpengaruh terhadap Tax Avoidance yang diukur dengan Effective Tax Rate. Aktivitas CSR yang dilakukan oleh perusahaan tidak mempengaruhi perusahaan agar perusahaan membayarkan beban pajak perusahaan lebih kecil. Penelitian ini juga menemukan Corporate Social Responsibility berpengaruh positif terhadap Tax Avoidance yang diukur dengan Book Tax Differences. Beberapa indikator aktivitas CSR yang dilakukan perusahaan merupakan pengeluaran yang dapat dibebankan sebagai biaya (deductible expenses). Perusahaan yang melaksanakan aktivitas Corporate Social Responsibility semata-mata hanya menggunakan tindakan yang socially responsible untuk dapat memperoleh image yang positif agar perusahaan dapat menutupi tindakan mereka yang socially irresponsible seperti 
penghindaran pajak. Hasil analisis tambahan menunjukkan bahwa keseluruhan aktivitas Corporate Social Responsibility tidak berpengaruh terhadap Tax Avoidance yang diukur dengan Effective Tax Rate, dan Corporate Social Responsibility berpengaruh positif terhadap Tax Avoidance yang diukur dengan Book Tax Differences. Beberapa indikator yang cukup signifikan positif yaitu pada indikator kinerja ekonomi (CSR1) dan kinerja sosial (CSR5).

\subsection{Keterbatasan}

Pada penelitian ini penulis menemukan beberapa keterbatasan-keterbatasan diantaranya, Penelitian ini hanya menggunakan sampel perusahaan non-keuangan, periode pengamatan 7 tahun $(2010$ - 2016). variabel independen yaitu Corporate Social Responsbility (CSR) yang di proksikan dengan metode cheklist dari Global Reporting Initiative (GRI) G3.1 Guidelines, Sales Growth, dan variable dependen Kinerja Keuangan Perusahaan yang di proksikan dengan ROA dan ROIC. Adapun saran untuk perbaikan penelitian kedepannya. Penelitian selanjutnya diharapkan dapat menambahkan sampel tahun penelitian dari semua sektor agar dapat mewakili populasi. Variabel Corporate Social Responsibility penggunaan item dengan mengadopsi GRI versi 4 agar hasil lebih akurat dan relevan serta menambah variabel lain yang berkaitan erat dengan Kinerja Keuangan Perusahaan seperti Net Profit Margin, Earning Per Share, dan Return on Sales. Selain itu pada penelitian selanjut nya bisa menambahkan variabel control seperti Leverage, Size, dan Capital Intensity.

\section{DAFTAR PUSTAKA}

Arini. (2016). Pengaruh Dewan Komisaris Independen, Komite Audit dan Corporate Social Rsponsibility Terhadap Tax Avoidance. Politeknik Negeri Batam. (Skripsi tidak di publikasikan).

Atmaja, L. S. (2008). Teori \& Praktik Manajemen Keuangan. Yogyakarta: ANDI Yogyakarta.

Basuki, A. T., \& Prawoto, N. (2016). Analisis Regresi dalam Penelitian Ekonomi \& Bisnis (dilengkapi aplikasi SPSS \& Eviews). Jakarta: PT Raja Grafindo Persada.

Candrayanthi, A. A., \& Saputra, I. D. (2013). Pengaruh Pengungkapan Corporate Social Responsibility Terhadap Kinerja Perusahaan ( Studi Empiris pada Perusahan Pertambangan). E-jurnal akuntansi Universitas Udayana, vol. 4.1 (2013), 141-158.

Erlina \& Mulyani, S. (2007). Metodologi Penelitian Bisnis untuk Akuntansi dan Manajemen. Medan: Usu Press.

Ghozali, I. R. (2013). Analisis Multivariat dan Ekonometrika : Teori, Konsep, dan Aplikasi dengan Eviews 8. Semarang: Badan Pernerbit Universitas Diponegoro.

Gujarati, D. N. (2012). Dasar Dasar Ekonometrika. Jakarta: Salemba Empat.

Hadi, N. (2011). Corporate Social Responsibility. Yogyakarta: Graha Ilmu.

Hartono, J. (2013). Metodologi Penelitian Bisnis: Salah Kaprah dan Pengalaman-Pengalaman. Yogyakarta: Edisi Keenam: BPFE-Yogyakarta.

Hidayati, N. N., \& Murni, S. (t.thn.). Pengaruh Pengungkapan Corporate Social Responsibility Terhadap Earnings Response Coeficient Pada Perusahaan High Profile. Jurnal Bisnis dan Akuntansi, Vol. 11, No.1, 1-18.

Lako, A. (2011). Dekontruksi CSR Reformasi Paradigma Bisnis \& Akuntansi. Jakarta: Erlangga.

EQUITY: Jurnal Ekonomi, Manajemen, Akuntansi | Vol. 22, No. 1 
Maksum, \& Kholis. (2013, Oktober). Ananlisis tentang pentingnya Tanggung jawab Social dan Akuntansi Social Perusahaan ( Corporate Social Responsibility and Social Accounting). Proceeding Simposium Nasional Akuntansi VI.Univ Airlangga Surabaya., 16-17.

Moerdiyanto. (2010). Tingkat Pendidikan Manajer dan Kinerja Perusahaan Go-Publik. Yogyakarta: FISE Universitas Negeri Yogyakarta.

Munawir. (2002). analisis laporan keuangan. yogyakarta: Liberty.

Oh, W., \& Park, S. (2015). Hubungan Antara Tanggung Jawab Sosial Perusahaan dan Kinerja Keuangan Perusahaan di Korea.

Rosiliana, K., Yuniarta, G. A., \& Darmawan, N. A. (2014). Pengaruh Corporate Social Responsibility Terhadap Kinerja Keuangan Perusahaan. S1 Ak Universitas Pendidikan Ganesha, Vol. 2 nomor 1, 1-11.

Sawir, A. (2005). Analisis Kinerja Keuangan dan Perencanaan Keuangan Perusahaan. Jakarta: PT Gramedia Pustaka Utama.

Sindhudiptha, I. S., \& Yasa, W. G. (2013). Pengaruh Corporate Social Responsibility pada Kinerja Keuangan Perusahaan dan Implikasinya Terhadap Nilai Perusahaan. E-jurnal Akuntansi Universitas Udayana, Vol. 4, 403.

Sujarweni, V. W. (2015). SPSS Untuk Penelitian. Yogyakarta: Pustaka Baru Press.

Tambunan, \& Porman, A. (2007). Menilai Harga Wajar Saham ( Stock Valuation ). Jakarta: PT. ElexMedia Komputindo.

Tsoutsoura, M. (2004). Corporate Social Responsibility and Financial Performance. Applied Financial Project Haas School of Business University of California. U.S.A , 1-21.

Wibisono. (2007). Membedah Konsep \& Aplikasi CSR ( Corporate Social Responsibility). Gresik: Fascho Publishing.

Widarjono, A. (2009). Ekonometrika Pengantar dan Aplikasinya (Ketiga ed.). Yogyakarta: EKONOSIA.

Wijayanti, F. T., Sutaryo, \& Prabowo, M. A. (2011). Pengaruh Corporate Social Responsibility Terhadap Kinerja Keuangan Perusahaan. Simposium Nasional Akuntansi XIV Aceh.

Winarno, W. W. (2015). Analisis Ekonometrika dan Statistika dengan Eviews (4 ed.). Yogyakarta: UPP STIM YKPN.

www.idx.co.id. (t.thn.).

Yaparto, M., Frisko, D., \& Eriandani, R. (2013). Pengaruh Corporate Social Responsibility Terhadap Kinerja Keuangan Perusahaan Pada Sektor Manufaktur Yang Terdaftar Di Bursa Efek Indonesia Pada Periode 2010-2011. Jurnal Ilmiah Mahasiswa Universitas Surabaya, Vol.2. No 1, 1-19. 